University of Louisville

ThinkIR: The University of Louisville's Institutional Repository

Electronic Theses and Dissertations

$5-1922$

\title{
A history of Ohio River trade at Louisville from its beginning until 1840.
}

John Edward Heller

University of Louisville

Follow this and additional works at: https://ir.library.louisville.edu/etd

\section{Recommended Citation}

Heller, John Edward, "A history of Ohio River trade at Louisville from its beginning until 1840." (1922). Electronic Theses and Dissertations. Paper 603.

https://doi.org/10.18297/etd/603

This Master's Thesis is brought to you for free and open access by ThinkIR: The University of Louisville's Institutional Repository. It has been accepted for inclusion in Electronic Theses and Dissertations by an authorized administrator of ThinkIR: The University of Louisville's Institutional Repository. This title appears here courtesy of the author, who has retained all other copyrights. For more information, please contact thinkir@louisville.edu. 
A

HISTORY OF OHIO RIVER TRADE AT LOUISVIILE

FROM ITS BEGINNING UNTII 1840. 


\title{
ONIVERSITY OF IOUISVIILE
}

$\Delta$

HISTORY OF OHIO RIVER TRADE AT IOUISVIIIE FROM ITS BEGINNING UNTII 1840 .

\author{
A Dissertation \\ Submitted to the Faculty \\ Of the Graduate School of Arts and Sciences \\ In Partial Furfillment of the \\ Requirements for the Degree \\ of Master of Arts
}

Department of History

By

John Edward Heller.

1922 
To Dootor Wilson P. Shortridge,

Teacher and Historian,

this work is most respectfully inscribod.

"And gladly wolde he lerne and gladiy teche." 


\section{BIBLIOGRAPHY.}

AlI1son, Y. E., City of Lonispil1e, Louisville, 1887.

Callender, G.S., Economio Hiatory of U. S., 1765 - 1860, Boston, 1909.

Casseday, B., H1storr of Lousarille Ti11 186R, Iouis $111 \mathrm{le}, 1852$.

Chevalier, M. Soolety, Manners, \& Polltice in

$$
\text { U. S., Boston, } 1839 .
$$

Clemens, S. I., Ilfe on the Mlsalsalppi, Hartford, 1901.

Dixon, F. H., Trafflo History of the Misgissippi Rivar, National Waterways Commisaion, Doc. No. 11, Wasington, 1909.

Drrrott, R. T., Centenary of Louistille, Loulo7111e, 1895.

Gephart, W. F., Transportation \& Industrial DeVolopment in Middle West, Now York, 1909.

Hall, Jea., Notes on the Wegtern States, Philadelphia. 1838.

Harper's Magazine, Peb. 1863, Editor's Table. Hezara, Sam, U. S. Comercial \& Statiatioal Rogister, Vol. 1, Jan. 1840. 
H1story of Ohio Fallo Clties, Vol. 1 \&11, Cleveland, 1882 .

Hulbert, A. B., the Ohio River, A Conrse of

Emp1re, New York, 1906.

Hulbort, A. B., Paths of Inland Commerce, New Haven, 1920.

Hulbert, B. B., P1lots of the Fopublio, Chicam go, 1906.

Joblin, M., Loul gvilie Past and Present, Iou1sVille, 1875.

Johnston, J. S., Memorial History of Loul oville,

Vol. 1, New York, 1896.

Mc Murtrie, H., Sketches of Loulsvilie and it 8

Environs, Iout sv1110; 1819.

Oge, F. A., Openting of the Mise18g1pp1, How York, 1904.

Otis, R. W., Ioulgville Directory for 1832 ,

Iouts71110, 1838 .

P1tkin, T., Statiatioal Flow, Hew Haven, 1835.

Turner, F. J., The Frontier in Amertcan Histo-

ry, New York, 1921.

Turner, F. J., Rlee of the Hew Woet, New York, 1906.

J. S. Engineors, Chief of; Ohio River Annual Keport, Wasington, 1873 . 


\section{TABIE_OR_CONTEATSS.}

Chapter.

I - TEE BODY OF THE NATION.

II : - PIONEERS OF OHIO RIVER TRADE UNTIJ 1810 .

III - 1810 to 1820 - TEE ADVENT OF THE STEAMBOAT.

IV - 1820 to 1830 - THE CONSTRUCTION OF THE CANAL AROUND THE FAIIS.

$\mathrm{V}$ - 1830 to 1840 - THE OPENING OF THE CANAI: THE DAWN OF A NEW COMMERCIAI FRA IN IOUISVILIE.

VI - CONCIUSION. 


\section{CHAPTIR I.}

\section{THE_BODY ON TEE_NATION:}

The dominent theme in the study of any phase of Ohio River history is found in the great extent of the river system and the vast area of the drainage bagin of the Miseisaippl to which this stroam forms so important a part. The basin of the Mississippl, as has beon aptly said, is the "Body of the Nation," a.1l other parts of the nation being but members, important in themselves, yet more important in the1r relation to this.(I) In extent it is the second great valley of the world, being exceeded only by that of the Amezon.(2) In a large sense the M18a18atppl veliey includes the whole interfor basin, a provinoe which drains into 2,000 miles of navigateble water of the Mfasissippl itsolf, 2,000 miles of the tawny flood of the Hissouri, and 1,000 miles of the Ohio, 5,000 miles of main weter highway, together with fifty-threo suborainate rivers, navigable by steamboats, ana some hundreds that are navigalable by flats and

(1) Harper's Magazine, Fob. 1863, Editor's Table.

(2) Tumer, Frontior in Amer. H1st. (N. Y. 1921) p. 179 . 
keols. With an area of nearly two and one half militon square miles of dreinage basin, this drainage basin excoeds in extent the whole of Eurape, exclusive of Rusila, Norway, and Sweden, and is estimated to be able to support a population of two or three hundred mililon - three times the prosent population of the whole nation. Conceptions formed from the river basins of Westorn Europe aro rudely shocked when we consider the extent of the valley of the Missisaippi; nor are those formed from the sterile basins of the great rivers of S1beria, lofty platerus of Central Asia, or the mighty swe pp of the swampy Amazon more adequate.(3) Iatitude, elevation, and rainfall all combine to render this valley by far the first place upon our globe as a dwelling place for civillzed man.

The setting for this perticular study lies on the Ohio River, the chief eastern tributary of this vast river system, reaching out toward and tapping the Atlentic coast states, thus providing the main course for the great commercial empire about to be called into being in the body of the nation. It is curious to observe thet from the very first beginnings of settlement in Loulsville, the unusual advantages of the location were seized

(3) See Ogg, Opening of the Mississtpple (N, Y. 1904) chap. 1. 
upon with prophetic instinct. It was before the days of the keelboats even, but the firstcomers recognized the strateglc importance of a location that was for a large part of the year at the head of naplgation of the vast ram1fications of the great Father of Waters with its tributaries lying west of the Falls of the Ohio. The growth and prosperity of the town, however well located it was, was obliged to walt upon the settlement of the country west of it and along the river. 


\section{PIONEERS_OF_OHIO_RIYKR_MRADE_WNTII_1810.}

The beginning of Ohio River trade ot Louisville can be traced to a very early period after the coming of General George Rogers Clark with a number of families to Corn Island on the Frils of the Ohio in 1778. These families become the founders of the City of Iouisville, and the Falls of the Ohio were never without inhabitanta after their arrival. The practical absence of internal communication by land for the purposes of trade led to the use of the river from the start as $a$ channel by which imfigration came to the Falls, and commodities for the use of the inhabitants were transported from Pittaburg and other upstream points. The commerce of the town was limited to these objects and points until the population of the valley became of sufficient number to look to New Orleans as a market for Western products and as a source of supply of foreign and domestic comodities not to be obtained at nearer points.

Wh11e there is an acoount of seteral trips made down the Oh10 and Mississippl by adventurous ploneers, it was not unt11 1782 that a veritable ommerclal voyage was made.(I) In that year two

(1) Cesseday, Higtory of Louigville, (Iouisville 1962) D. 62 
French trader nemed Terdiveau and Honore, made the first trading voyage from Red Stone 01d Fort - now Brownsville - on the Monongehela, to New Orleans. They subsequently settled in Iovistille and continued to reside there a merchants and traders until their death.

In May, same year, Captain Jacob Yoder, from the same point, descended the Ohto and Misslssippi in the first platboat - as is inscribed on his tombitione in spencer county - that ever carrled a cargo of produce to How Orloans. Here he sold hls cargo to the Spanish comandant, takIng in payment a draft on the Captain-General of Cuba. Proceoding to Havana, Yoder Invested the. proceods of his draft in furs and hides, which he took to Baltimore and sold at a profit.(2) Thus was begun a system of exchange which became in time quite common; the proceeds of the sales made in Eatern markete being invested in merchandise in Philadelphia and other cities, which was brought west on pack mules, and the profits from their sale re-invested in Wostern produce, shipped to New Orleans and disposed of as before. Jacob Yoder also made frequent trips in flatboats from his farm on the waters of Salt River with produce to New Orleans and is recognized as the pioneer in Western

(2) Johns ton, Momorial H1story of Iout grilio, (N. Y. 1896) I. P. 244 . 
commerce.

As the population and the products of the so1I Increased, commerce became mare extended, furs, hides, and salt being also added to the cargoes. General James Hilkinson, who came to Kentucky in 1784, added largely to the trade, especially after 1787 when he made a private commercial arrangement with the Spanish Gorernor at New Orleans by which he was onabled to ship produoe to that point on adrantageous terms and to import thence to Kentuoky sugar and other commoditieg. In 1786 he was engaged, among others, in extensive schemes in dealing in salt made at Bullitt's Ilck, near Ioulsvi110.

In 1787, Crevecour, Aranch traveler in the West, speaks of coming to Lonlsville from Pittaburg In a flatboat loaded with brloks, boards, bars of iron, coal, Instruments of husbandry, alsmounted wagons, anv11s, bellows, dry goods, brandy, flour, biscuits, hams, lard, salt meat, etc. On the tenth day he arrirod at Louisvilie, of whioh he says: "Already this I1ttie c1ty, the metropolis of the country. contains articles of merchandise which contributes on the one hand to support the trade in sking from Venango and the peninsula of lake Erie by the River Miami, Muskingum, and Scioto, and on the other hand, to descend tho Ohio to supply the wants of the fermers of Indiana, of Kemtucky, the Fabash, and even 
of IIIInois, Cattle, propisions, I1me and brick made in Pittsburg, are shipped dally to Loul sville." (3)

The commerce of Loulsvilie thus inaugurated in the simplest form of exchange of commodities In the Oh10 River trade developed and expanded gradually with the settlement of Kentucky and the West. The souare-end flatboat, used for downstream carriage, was supplomented by the barge and the kelboat with pointed brow, which, with sails and oars, was used for bringing cargoes upstream from New Orleans. This trade was stimulated by the Treaty of 1795 between United States and Spain, which gare to the inhabitants of the West the Iree navigation of the Mississippi River with right of deposit at New Orleans. Ioutsville was made a port of entry by Act of Congress in Norember 1799. and a collector appointed to prevent the clandestine Importation of foreign goods, to which previously there had been no check, New orleans being a foro1gn port.

At that time there not one route to the great marts of the Eastern coast which was practical thru the whole year, and there was not capital enough to undertake one. All the commerce of the West was carried on by the Ohio and the Mississippi, which is, indeed still, and probably always will be, 
the most economfcal route for bulky objects. The western boatmen descended the rivers with their corn and salt meat in flatboats, and the goods of Europe and the produce of the Antilies were slowly transported up the rivers by the ald of the oar and the aril, the royage consuming at. least one hundred days and sometimes two hundred. One hundred days is nearly the length of a voyage from Hew York by the Cape of Good Hope to Canton; in the same space of time France was twice conquered, once by the allies, and once by Iapoleon. The commerce of the West wa, therefore, necessarily very limited, and the inhabitants separated from the rest of the world had all the rudeness of the forest. It was in this period and this state of affairs that the popular saying which describes the Kentuckian as half horse, helf alligator, had its origin. The number of boats which made the royage up and down, once a year, did not exceed ten, measuring on an average about one hundred tons. Freight from How Orleans to Louisville was 6,7 , and even 9 cents a pound. (4)

The close of the first decade of the new century found Louisville with a slowly increasing number of inhabitants and a growing industry - the

(4) See Callender, Economic History of U. S. (Boston 1909) p. 361. 
trade afforded by the Ohio River - which offered an inducement for enterprise and capital. (5) Upon the acquisition of Iouisiana in 1803, and 1mproved navigation, culminating in the successful use of steam as a prapeling power, the prosperity of Ioulsville as a commerclal center was assured; and a new era in the history of Ohio River trade was inaugurated.

(5) Hulbert, Ohio Fiver, A Course of Emplre, (N. Y. 1906) chep. XI, From Pittsburg to Ioulsville in 1806. 


\section{0_to_t1820_=_THE_ADVENT_OP_THE_STEAMBOAT.}

The opening year of the decade 1810-20 saw the inauguration of an event that was destined completely to revolutionize transportation by water. In October 1811, the first steamboat that ever moved upon any of the waters of the Mississippi valley made her appearance at Louisville.(I) From this event dates the substantial development of Oh1o River trade and commeroe, and the growth of Iouiorille in population, manufaotures, and all the varied elements of a city.

The evolution of the steamboat from the rude craft of the pioneer to the palatial siae-wheoler, capable of bearing swiftly thousand of tons of freight and hunareds of passengers in comfort and elegance is one of the most interesting incidents in the settlement of the West. Iong before the Indian had ceased to harass the ploneer settlers, the chief route of immigration and commerce was by the Ohio from P1ttsburg. The boats used for this transportation were of various sizes, but of uniform pattern, of rectangular frame, square at both onds, with broad thick ganwales, which, in case

(1) Durrett, Contenary of Louisville,

(Loulstilie, 1893) p. 83. 
of attack, would protect the ocoupants from the arrows and rifle-balis of the Indians. Sometimes they were open, but generally a part of them was partitioned off and coverea with a low, flat roof for protection of the passengers and their effects from the weather. One or more palrs of large oars on either side and a large oar or sweep at the stern for steering, completed the equipment of this primitive craft which was called by the various names of ark, family bost, and broadhorn. The latter appellation has survired, and the early style of aquat1c architecture can stili be recognized in the shenty boat used for residence and small traffic olong the shores of western rivers, and in the various small crafts employed in bearing hay and other products of the fleld, forest, and mine to downstream markats.(2)

The broadhorn had its uses, but for stemming the current a modification of the keel was necessary. Th1s was furnished by the model of what was known as the keolboat, which was introduced at an early day by the French and propelled by expert boatmen, known as voyagours. A keolboat was generally manned by ten hands, principally Canadian-French, and a patroon or master. The bont seldom carried more than twenty or

(2) Johnston, Memorial History of Louigvilie, I, p. 309; Hulbert, Ohio River, A Course of Empire, chap. I, From Keelboat to Schooner. 
thirty tons. Barges had frequently a crew of forty or fifty mon with a patroon, and carried fifty to sixty tons. Both of these kinds of vessels were provided with a mast, a square sail, and coils of cordage. By means of oars, sail, poles, and ropes for cordeling, this style of boat was adapted for overcoming the resistance of strong currents.(3)

Audubon, the famous naturalist and traveler, in an account of his Western travels relates how a barge that left Hew Orleans on Narch 1 often did not reach the Falls of the Ohio until July, sometimes not until october. A barge that camo up in three months had done wonders; and after all the Immense trouble it brought only a few bags of coffee and, at most, one hundred hogsheads of sugar. (4) The number of barges at that period did not amount to more than twenty-five or thirty, and the largest probably did not exceed one hundred tons burden. Such was the state of things at the adrent of the flrst steamboat.(5)

The improvement in steamboats was so rapid, and the incidents attending them so interesting and $v i-$ tal to the development of Ohio River trade, that a particular history of a few of the earliest steam-

(3) Casseday, History of Louisville, p. 64.

(4) Johnston, Memorial History of Louisville, I, p. 310

(5) Casseday, History of Louisville, p. 67. 
boats that were bullt can hardly be considered a digression from the theme of this paper.

The first steamboat on the Western waters, the Orleans, built at Pittsburg in 1811, was owned and constructed by Robert Fulton. She was a side-wheel, single deck rossel of a tonnage variously estimated at from 200 to 400 tons burdon. She had but a single boiler, which was placed in the hull of the ressel, and the padale wheels were without boxing to conceal them from view. Her smokestack rose from the center, with masts fore and aft, and her cabin covered the middle three-quarters of her deck, leaving but oneeighth in front and rear for an open deck. She. had a low-pressure engine, which afforded power onough to drive her from Pittsburg to Louisville the fourth day after she sot out. When she reached Iouistilie, the water was too low for her passage over the rapids; and she ran between Louisville and Cincinnati until a Novomber rise enabled her to pass the Falls. She arrived at Loulsville in the night and created no little consternation by the noise of her steam as she rounded to at the foot of Fourth Street. Many of the good people, used to the quiet glidings of the keels and flats, were aroused from their slumbers and repaired to the wharf to see what was the matter. Others were so terribly frightened that they slept no more during the night and feared the end of the world was at hand. Barly 
in December, 1811, the river having risen, the Orleans sailed to Now Orleans. She reached New Orleans safely Decomber 24, and plied between that place and Natchez until July 14, 1814, when she was sunk by a snag. (6)

The sec ond Ohio River steamboat was the Comet, a stern-wheoler of 45 tons, built at Pittsburg in 1813. She made a voyage to Louisville in the summer of 1813, descended from Now Orloans in the spring of 1814, made two voyages thence to Natchez, and was dismantled and the engine put in a cotton-gin. (7)

The third steamer was the Vesurius, of 390 tons, built at Pittsburg by Robert. Fulton in 1814. She sailed from New Orleans in the spring of 1814 where she took the place of the Orleans in the Natchez trade, in which she romained until her ond in $1820 .(8)$

The fourth steamboat was the Enterprise, of 45 tons, built at Brownsville, Pa. She made two trips from Pittsburg to Louisville in the summer of 1814 and then went to New Orleans with a cargo of ordinance stores. She arrived there December 14 and proved of great service to General Jackson in the operations pending the Battle of New Orleans.

(6) Joblin, Louisville Past and Present, (Iouisville 1875) p. 20.

(7) Hall, Notes on Western States, (Phil. 1838)p.230. (8) Ibid. p. 230. 
On May 6, 1815, she again set out for P1ttsburg, under command of Captain Shreve, and arrived at Shippingport (Iouisville) May 30, twenty-five days out, the first steamboat ever to arrive at this port from New Orleans. This was regarded as a great feat, as indeed it was, considering the fact that she ran only in the day time, for there were no wood-yards and she was obliged to tie up while the crew cut wood from the forests on the bank. Thus had captain Shreve accomplished in twenty-five days, a trip which previous to that time had never been accomplished in iess than three months. The Enterprise, under the command of Captain D. Worley, then proceeded to Pittsburg bat was lost in Rock Harbour, Shippingport.(9)

The fifth steamboat was the Astna, of 390 tons burden, built at Pittsburg in 1814. She sailed from Pittsburg to New Orleans in Narch, 1815, and then went into the Natchez trade.(10)

The sixth boat was the Despatch, of 75 tons, built at Brownsville in 1817. She made several voyages from P1tteburg to Louistille, and one from New Orleans to Shippingport, where she became a wreck in 1820. (11)

The seventh and eighth boats were the Buffaloe

(9) Ibid, p. 231.

(10) Ibla, p. 231 .

(11) Ibia, p. 232 . 
and the James Monroe, of 250 and 150 tons burden respectively, bullt at Pittaburg in 1816 . The Buffaloe became worn out and useless in 1819, and the James Monroe was lost on the lower Mississtppi in 1821.(12)

It was not until the appearance of the Fashington, the ninth steamboat in order of construction, that the practicability of steamboat nevigation was assured. She was designed and constructed by Captein Shreve at Whoeling, Va., and was destined to revolutionize completely the narigation of the West. The engines and boilers of all previous boats had been placed in the hold and had but one dock, but on the Waghington Captain Shreve placed them on the main deck and built an upper deck for passengers. Thle design has been the model for boats on the Western rivers over since. Sho was completed in September, 1816, and made a successful trip to Loul sville and thence to New Orleans and returned to Loul sville in the early winter. In March, 1817, Captain Shreve left with the Washington on her second trip and returned, having boen absent from Louisville but forty-fivo days. This was the trip that first convinced the discouraged public that steamboat navigation would succeed. (13)

In 1818, the General Pike, the first steamboat 
on Western waters designed for the exclusive conrenience of passengers, was constracted at Cincinnati and plied as a packet betwwen Maysville, Cincinnati, and Iouisville. Boats previously built had been intended solely for transportation of merchandise; these objects subsequently were successfully united. (14)

In 1819 the first attempt on Western waters to carry mail by steamboat was made. The Post Boy, 200 tons, built at Now Albany by Captain Shreve and others was designed for the conveyance of mail between Iouisville and New Orleans, under an Act of Congress pessed March, 1819.(15)

The progress that was made in steamboat narIgation and the difficulties that frowned upon this enterprise can thus be seen in the history of a few of the first boats in their regular order. The first advance was slow and the prospect very aiscouraging. The fourth boat that descended the river was the first to re-ascend as far as Loulsville, and even then it wes considered doubtful whether steamborts could be rondered useful as a mode of navigation for ascending trade. It was not until 1817, when the boat that was ninth in order of building, which made the trip from Iouisville to New Orleans and back in 45 days, that the question of practicability was considered settled. 
It was not long after the first steambat at Iouisville before the former makers of keols and barges were at work making steamboats. The old boat-yards at Shippingport and above the mouth of the Beargrass were turned into rogular ship-yards, and so were those across the river at Now Albany, Clarksville, and Jeffersonville. The Governor Shelby, launched in 1816, was the first steamboat built entirely at Iouisville, but when Dr. Me Murtrie published his History of Louisville in 1819, he gave a list of no less than eight that had gone out from fards in and about Ioulsville, and as many more being built.(16)

From 1812 to 1819 there had been built and employed in navigation on the Ohio and Mississippi Rivers 68 steamboats, of the first 41 of which seven were built by Kentuckians and twenty-four owned by them. The size of the boats were increased until 1819, when the United States, built at Jeffersonvilie, with duplicate engines made in England, measured 700 tons. A chronicler of the day says, "She is doubtless the gaint steamboat in the universe, drawing but little water and capable of carrying 3,000 bales of cotton:"(17)

The impetus given to river trade by the introduction of the steamboat was reflected in the substantial growth and development of Louisvillo

(16) Johnston, Memorial H1story of Jouisville, p. 72 . (17) Ibid, p. 312 . 
and Shippingport. In 1812 Paul skidmore started an iron foundry which was the forerunner of many establishments for making castings and steamboat machinery. A sugar refinery, two steam saw mills,. a nail factory, two carriage factories, several distilleries, flow mills, and pork houses, and numerous other manufactories were started at this time.

In 1819, the principal oxports were steam engines, beef, pork, bacon, lard, flour, whiskey, tobacco, and formerly hemp. In addition to the above articles may be added various pieces of household furniture, as beds, sideboards, chairs, etc. of the quantity of pork packed in Louisville at. this time - which afterward became the leading business of the city, in which she had few rivals Dr. Mc Murtrie seys, "that one individual during the jear 1818 shipped 9,000 barrels, averaging 320 pounds, a total of $2,880,000$ pounds."(18)

To Shippingport, also, the rival of Louisville as a commercial point, the steamboat in its early Jears brought a great urge forward; so much so, that in 1818 Iouistille and Shippingport were put on qual footing. John and Louis Tarasc on had bought the greater part of the townsite of shippingport in 1806. It was then considered an important place on account of its being at the head of

(18) McMurtrie, Sketches of Louigville, (Louisville 1819) p. 55. 
navigation of the lower river, as Loulsville was the port of that of the Upper Ohio, where all ascending boats were compelled for three-fourths of the year to discharge their oargoes. The population had increased by 1818 to rival that of Iouisville. It boasted many handsome houses. Shippingport, according to $\mathrm{Dr}$. MoMurtrie, was called the "Bols de Boulogne" of Louisville, it being the resort of all classes on high days and holidays. At the se times, it exhibited a spectacle at once novel and interesting. The number of steamboats in the port, each bearing one or two flags, the throng of horses, carriages, and gigs, and the contented appearance of a crowd of pedestrians, all arrayed in their "Sunday's best," produced an offect impossible to describe. There were rope-walke there where cordage was made; the Napoleon Distillery, where were made different kinds of distilled waters, cordials, and liqueurs; and above all the great flour mill which cost the Tarascons $\$ 150,000.00$. The building was six stories high and was oquipped with the most expensive machinery imported from France. The capacity of the mill was 500 barrels of flour a day. Its pover was derived from the Falls of the Ohio thru a channel cut for the purpose, the first of a long series of attempts to harneas the power of the falls for commercial purposes.(19) All this was destined 
to fade away when the canal was built in the next decade, and Iouisville became both the head and the foot of the Falis. 


\section{0 to 1830}

\section{THE_CONSTRUCTION OF THE CANAI AROUND THE FAIIS.}

After the demonstration by Captain Shreve of the practicability of navigation by steamboats upstream as well as down with safety and alspatch, the building of boats received a fresh stimulus. The obstruction to navigation by the Falls, however, soon made evident the need of constructing a canal to aroid the necessity of a portage in low weter. Although this improvement, as one benefiting the commerce of the entire Mississippi valley and all its tributary territory, was a proper subject for Federal construction and control, it was left for the State of Kentucky, and largely the city of Louisville to inaugurate it and carry it to completion.

The project of a canal around the Falls was entertained in the beginning of the settlement of Louisville. When the town was founded there is reason to believe that the enormous value of a canal around the Falls had been suggested. At what time the project was first proposed cannot be stated accurately. Certain it is that a map of the town, drawn in 1793, presented the projected canal virtually as it was built thirty-seven years later. 
This map appears in a book entitlod A Topographioal Description of Horth America, by Gilbert Imlay, published in Iondon in 1797.(I) It is interesting to know that one of the first agitators of the canal project was General James Wilkinson, who settled in Lexington in 1784. General Wilkinson frequently visited Iouisville, and the canal project was one that seems to have occupied his mind to a considerable extent. In 1804 a canal company was chartered, but nothing was done bejond surveys for many years after this time.

By an Act of the Kentucky Iogislature of Jenuary 12,1825 , a corporation wa chertered by the name of the Louisville and Portland Canal Company, to. construct a canal around the Falls of the Ohio River in three years, with a right to levy tolls on vessels passing thru the canal. The United States, under Acts of Congress, became a stock holder in the company. Actual work was begun under this charter in 1826, but greater obstacles presented themselves than had been expected, and the Canal Company found it necessary to obtain an extension of another three years in which to complete the work begun. The canal was completed within this latter limit.(2) On December $21,18 \frac{2}{9}$, the first ateamboat, the Uncas - a good

(1) Allison, City of Louisville, (Louisville 1887)p.4.

(2) Ohio River Annual Roport, Chi of of U. S. Engrs., (Washington 1873) p. 8. 
name for an adventurous vessel - squeezed thru the canal, although the work was yot far from ready for business. (3) The cenal was about two miles in length and cost $\$ 750,000,00$ when first constructed. The canal would have been begun and completed long before it was but for conflicting interests of the Indiana side of the river. The Indiana influence retarded the work from the time the first charter was granted by the Kentucky Iegislature in 1804 unt1l it was begun under the now charter of 1825.

In spite of the hard times which followed, the general bankruptcy prior to 1820 and which continued thru the decade, Louisville steadily grew in importance as a commercial center for Ohio River trade. Daring this decade the population of Iouisville was doubled. The number of steamboats in service on the Ohio River increased from 72 in 1821 to 200 in 1829 with a grand tonnago of 35,000 tons.(4) As steamboats became more efficient, the time required for the trip from New Orleans to Louisville was gradually decreased. In 1821, Captain Pierce, in the Car of Commerce made the voyage from New Orleans to Shawneetown, a little below Louisville, in ten days, as compared with twenty-five days required by the Enterprise in 1817. In 1825 after fourteen years of experiments and trials

(3) Durrett, Centenary of Louisville, p. 78.

(4) Casseday, History of Iouisville, p. 173. 
the proper proportion between the machinery and boat was inally settled.(5) Two years later the Tecumseh ascended from Now Orleans to Iouisville in eight days and two hours, a record trip for this decade.

(5) Callender, Economic History of U. S., p. 363; also see Turner, Rise of Hew West, (New York 1906) chap. VII, Western Commerce and Ideals (1820-3I) 


\section{CHAPTER V.}

1830 to 1840
THE OPENING ON THE CANAI:

THE DAWN OF A NEW COMWERCIAI ERA IN IOUISVILLE.

The year 1830 saw the successful completion of the canal and the commencoment of the commerc1al prominence resulting therefrom, which Louisville has held so long. The times were propitious for such expansion. Steamboat navigation was no longer an experiment. The tide of immigration which had so rapidy increased the population of Kentucky during the last decade continued undiminished, and Kentuoky was lifted from the fourteonth to the sixth state in order of population. During this decade the population of Ioulgville was again doubled. The hard times and general business depression of the twenties were changed to days of thrift, prosperity, and enterprise. New Orleans sprang into sudden commercial importance from the cotton and other agricultural products which poured into that city from the rapialy developing country along the Mississippi and its tributaries. Vicksburg and Natchez became thrifty towns, while Louisville assumed a commercial importance at the northern ond of the line corresponding with that of New Orleans at the southern. She became the distributing point of both the migrat- 
ing population and the supplies necessary for their maintenance.

The topographical feature which attracted its early settlers to the Falls as the point likely to become a city on account of the obstruction to nevigation and the consequent nocessity of portage seems early to have been regarded as an important factor in its development as the country increased in population, traffic, and travel. That the theory and the policy pursued thereon were unsound and operated in the long run as a disadrantage; cannot be questioned, as evidencod by the greater progress and development in every respect since the enlargement and froodom of the canal, the construction of bridges, and other facilities for rapld and unobstructed transportation. But certain it is that for a long time individual and municipal effort was exerted to derive as much profit as possible from the obstruction, which the canal only partially relieved. In the first place there was a toll upon all steamers or other river craft of 80 cents a ton, but soon reduced to 50 cents, rated by the capacity of the boat and not by her actual load,(I) Thus boats from and to downstream points, unloaded and took on passengers and Preight destined for the South at Portland instead of Louisville, thereby avoiding passage thru the canal. But the profit derived by the drays

(1) Johnston, Memorial History of Iouisville, p. 313. 
and hacks was perhaps the most potent factor in the effort to increase rather than remove this tax on transportation. Even until within the memory of many citizens there was a systematic obstruction to free trade thru Louisville, which did not disappear altogether until 1880 .

The stimulus given Ohio River trade at Iouisville by the completion of the canal and the development of population and agriculture in the West and South, resulted in a rapid increase in number and size of steamboats employed in river transportation. A largo amount of capital was inrested in the business, and Iouisville became the leading city in the ownership and management of steamboats penetrating all the rivers tributary to tho Ohio and Mississippi. Steamboat-building, especially the building and oquipment of steamboats of the larger class, became a loading industry in Louisville; but the better location for ship yards at Jeffersonville led later to its transfer to that point. The number of steamboats on Western rivers January 1, 1834 was according to estimation about 230, measuring 39,000 tons, twenty-five of which over 200 tons each, plied between Louisville, New Orleans and cincinnati. The number of flat bottom and keelboats was estimated at 4,000 , with tonnage of 160,000 tons, making the grand tonnage of Western waters about $200,000 .(2)$

(2) Pitkin, Statistical V1ow, (New Haven 1835) P. 536. 
A conception of the actual conditions on the steamboats: plying the Ohio and the Mississippi during this period can best be obtained from the following account of Chevalier, a French traveler in these parts in 1836:

"The number of passengers which these boats carry is very considerable; they are almost always crowded, although there are some which have two hundred beds. The rate of fare is low; one goes from Pittsburg to New Orleans for $\$ 50.00$, all found, and from Iouisville to New Orleans for $\$ 25.00$. It is still lower for baatmen, who run down the river in flatboats and return by steamers; there are sometimes five or six hundred of them in a separate part of the boat, where they have shelter, a berth, and fire, and pay from $\$ 4.00$ to $\$ 6.00$ for the pessage from New Orleans to Iouisville; they are, however, obliged to help take in wood. The rapidity by which these mon return has contributed not a little to the extension of the commerce of the West; they can now make three or four trips a year, instead of one, an important consideration in a country where there is a deficiency of hands. On the downward royge their place is occupied by horses, cattle, and slaves which are sent South for sale."(3)

In the same way other industries were founded as the demand grew and as capital could be spared.

(3) Callender, Economic History of U. S., p. 363. 
from commerce which was the overshadowing pursuit engaging the leading and most enterprising citizens.

Tobacco had become a stable crop for Kontucky and Southern Indiane and found its chief market in Louisville where it was shipped to New Orleans. Tobacco manufactories were established, and cigars were produced on a rather large scale. This industry has increased with the growth of Loulstille until it has become the largest tobacco market in the world.

Pork packing at Louistille, beginning shortly after the navigation of the river by steamboats had become an asoured success, increased rapidy during this decade until Iouisville stood among the firgt in this industry, the South drawing its supplies from this city. Shipments of bacon and other pork products from Loulsvilie embraced foreign as well as domestic markets. The gradual economic emancipation of the South by home production, and the concentration of this industry at Chicago and a few other points for supply of foreign markets, led to the gradual reduction of this industry antil it has become a minor industry. As a by-product of the pork packing industry, Louisvillo developed oarly into a center for the manufacture of soap and candles; and a trade was built up in these wares that extended to Europe. 
a supply of grain and a market for the product carly led to the establishment of flour mills and distilleries at Iouisville. During this decade these industries flourished and furnishod a great percentage of the export tonnage of Loufsville.

Some 1dea of the amount of Ohio River traffic can be obtained by the commercial statistics of importation to Louisville from December 1, 1831 to August 4, 1832, which were as follows: (4)

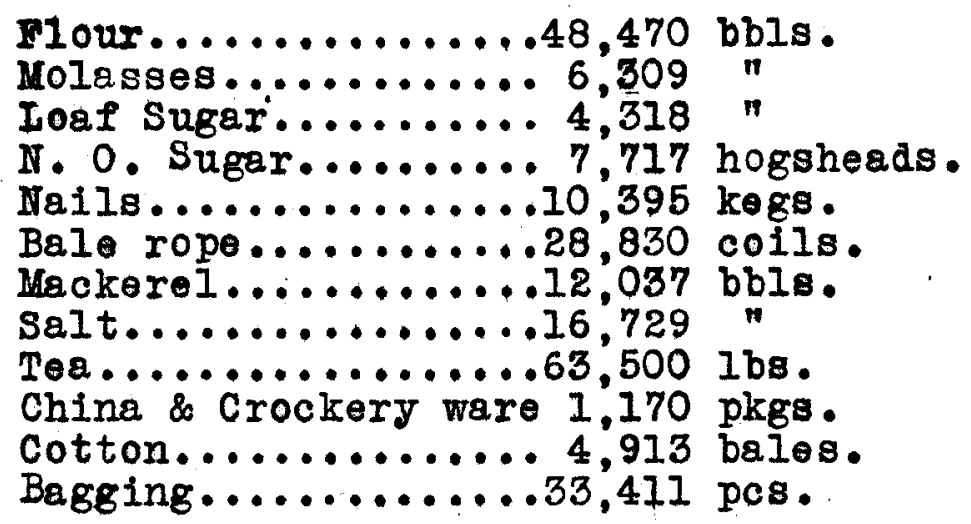

In 1835 for six monthe ending June 30 exports from Louisville were as follows:(5)

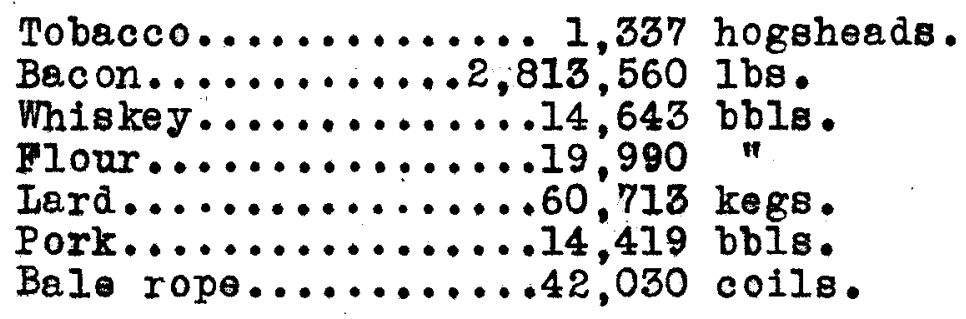

This indicated the large expansion of commerce as the direct result of the opening of the canal, Increased tonnage of ressels, and development of population and agriculture in the West and

(4) 0t1s, Louisville Directory (Louisville 1832) p.153. (5) Johnston, Memorial History of Louisville, I, p.245. 
South. Commerce was the chief business of Iouisville, a large capital being invested in it; and the best business talent ongaged in the forwarding and commission business.

The growth of Ohio River traffic at Louisville is graphically shown in the following abstract of the boats that passed through and tolls received on the Louisville and Portland Canal for the decade:(6)

$\begin{array}{ccccc}\text { Yoar } & \text { Steamboats } & \begin{array}{c}\text { Flats and } \\ \text { Keelboats }\end{array} & \text { Tons } & \text { Tolls, } \\ 1831 & 406 & 421 & 76,323 & \$ 12,750.77 \\ 1832 & 453 & 179 & 70,109 & 25,756.12 \\ 1833 & 875 & 710 & 169,885 & 60,736.92 \\ 1834 & 938 & 623 & 162,000 & 61,848.17 \\ 1835 & 1,256 & 355 & 2,413 & 80,165.24 \\ 1836 & 1,182 & 260 & 182,220 & 88,343.23 \\ 1837 & 1,501 & 165 & 242,374 & 145,424.69 \\ 1838 & 1,058 & 438 & 201,750 & 121,107.16 \\ 1839 & 1,666 & - & 300,406 & 180,364.01 \\ 1840 & - & - & - & 134,904.55\end{array}$

A comperison of the statistics for the year 1831 and 1839 in the table above shows a commercial increase that is typical of this decade. The tolls collected for the year 1839 are the greatest for any year until 1872 when tolls were abolished, except the years 1866 and 187l; the value of tolls in 1866 being $\$ 180,925.40$ and for the year 1871,\$207,025.19.(7)

In this period Loulsvill was purely a commercial city handing the manufactures of the East and the great agricultural products of Kentucky developed by

(6) Hazara, U. S. Commercial \& Statistical Kegister, I. $1840, p .32$.

(7) Ohio River Annusl Report, Chief of U. S. Engrs., (Washington 1873) p. 13. 
slave labor. The city grew rapidily in wealth and in importance, but it could not grow in an independent and couragoous common population because the blot of slave labor kept white mechanics of the best classes away. It was in this decade that Ioulsville established her social and political power, and became the resort of the most cultivated classes of the South who were attracted by the temperate climate and healthfulness of the place. 


\section{CONCIUSION.}

The important role played by Louisville and its early citizens in the most vital act in the phenomenal drama of American development - the settlement and founding of a coloseal empire within the heart of the nation, the incomparable Mississippi basin - cannot be over-ostimated. In the oponing scene of this drama we saw the coming to Corn Island of that heroic character, Goneral George Rogers Clark, with a group of rugged pioneer families, whose prophetic sight saw the vision of a great commercial metropolis rise out of the silent wilderness about the Falls of the Ohio, the atrategic portal to the great West and South beyond. Four years later the apparently inconsequential passing by this settrement on the Falls of the Ohio of the adventurous French traders Tardiveau and Honore, the first to make a veritable commercial voyage down the Ohio to New Orleans, was fraugh with slgnificance. Likewise the performance of Captain Yoder, the pioneer of Western commerce, who, in the same year, descended the Ohio and Mississippi in the first flatboat that ever carried a cargo of produce to New Orleans 
affected the destiny of Loulsville profoundly. It was ho who established that cycle of trado in whlch Louisvilie played an important part for many years, embracing Ohio River ports, New Orleans, Havana, eagtern Atlantic markets, and back to Ohio River ports again.

The whole tenor of the story of pioneer trade on the Ohio River was influenced by these events. Ioulsville became the renderouz of all who were interested in the conquest of territory, the courageous schemes of developing a river commerce with Spanish provinces, and the building of a canal through which passing commerce might pay toll to the enterprise of Iouisville. It is during this phase of the story that General James Wilkinson, the perennially interesting rouge of pioneer times, together with Aaron Burr, appear temporariliy upon the scene.(I) The fact that Yoder and both. Tardireau and Honore, with their first-hand knowledge of the river and contiguous territory from Pittsburg to New Orleans, subsequently chose to settle in Louisville or its vicinage and reside there as merchants and traders until their deaths, proves conclusively the strategic importance of Louisville in the development of Ohio fiver trade and the commercial empire within the body of the nation during the tremendous

(1) Allison, City of Louisville, p. 4. 
days of pioneer history.

Iike a hero in the drama, the steamboat made its appearance at the psychological moment. The romance of the evolution of the steamboat, the unequal combat between the steamboat and its predecessors, the broadhorns and barges, and the story of Shippingport in its halcyon days of prosperity, gaiety, and culture forms an absorbing interlude in this great drama. The position of leadership which Iouisville assumed in this phase of Ohio River trade and traffic again substantiated the vision of the pioneers on Corn Island.

The triumphal completion of the Louisvilie and Portland canal through the initiative and perseverance of the early citizen of Louisvillo against political opposition and great physical obstacles, forms the climax of the great drama. The era ushered in by the intrepid Uncas in 1829, the increased tonnage of steamboats, and the rapid development of population and agriculture in the West and south culminated during the decades immediately preceeding the Civil War, before the era of railroad diverted the trade and travel from the rivers, in the golden age of steamboat traffic on the Ohio(2) and in the com-

(2) See Hulbert, Ohio River, A Conrse of Empire, chap. XIV., When the Steamboat was King. 
plete realization of the pioneers' drean of a commercial metropolis at the Falls of the Ohio.

$$
\begin{gathered}
* * * * * * * * * \\
\text {-Finis- }
\end{gathered}
$$

